\begin{tabular}{l} 
Aving Tera \\
LingTera, 5 (1), 2018, 1-9 \\
\hline
\end{tabular}

\title{
Alih kode dan campur kode tuturan di lingkungan pendidikan
}

\author{
Ruth Remilani Simatupang *, Muhammad Rohmadi, Kundharu Saddhono \\ Fakultas Keguruan dan Ilmu Pendidikan, Pascasarjana Universitas Sebelas Maret. \\ Jl. Ir Sutami 36 A Surakarta, 57126, Surakarta, Indonesia \\ * Corresponding Author. Email: ruthremilani@gmail.com \\ Received: 5 April 2018; Revised: 7 March 2018; Accepted: 28 May 2018
}

\begin{abstract}
Abstrak
Penelitian ini bertujuan untuk mendeskripsikan alih kode dan campur kode yang digunakan oleh penutur di lingkungan SMK di kota Medan. Penelitian ini merupakan penelitian deskriptif kualitatif. Subjek yang digunakan dalam penelitian ini adalah bahasa-bahasa yang digunakan oleh guru dan siswa pada saat pembelajaran bahasa Indonesia. Objek dalam penelitian ini adalah tuturan penggunaan alih kode dan campur kode yang digunakan dalam pembelajaran bahasa Indonesia. Metode yang digunakan dalam mengumpulkan data adalah teknik pengamatan, teknik wawancara dan teknik rekam. Hasil penelitian menunjukkan bahwa alih kode dan campur kode yang terjadi ialahbahasa Batak,bahasa Inggris dan bahasa Indonesia. Jenis alih kode yang ditemukan adalah bahasa Indonesia ke bahasa Batak. Jenis campur kode yang ditemukan adalah campur kode ke dalam dan campur kode keluar dengan menggunakan bahasa Indonesia, bahasa inggris dan bahasa Batak dengan bentuk kata, kelompok kata, kata ulang, ungkapan dan klausa.
\end{abstract}

Kata Kunci: alih kode, campur kode, pendidikan.

\section{Code switching and code mixing on the speech of education environment}

\begin{abstract}
The research aims to describe code switching and code mixing that are used by speaker in vacation high school at Medan. This research is a qualitative descriptive. The subject of this research is languages used by teacher and students in learning Indonesian. The object of this research is code switching and code mixing used on learning Indonesian.The method used to collecting the data are observational echniques, interview techniques and recording techniques. The result shows that languages undergoing code switching and code mixing are English,Bataknese and indnesian. The type of code switching found is Bataknese languages to Indonesian languages.furthermor, the type of code mixing found is inner code-mixing and outer code -mixing by using Indonesian language, English and Bataknese with the form of the word, group of words, repetition of word, expression and clause.
\end{abstract}

Keywords: code switching, code mixing, education

How to Cite: Simatupang, R., Rohmadi, M., \& Saddhono, K. (2018). Alih kode dan campur kode tuturan di lingkungan pendidikan. LingTera, 5(1), 1-10. doi:http://dx.doi.org/10.21831/lt.v5i1.19198

http://dx.doi.org/10.21831/lt.v5i1.19198

\section{PENDAHULUAN}

Sosiolinguistik adalah kajian tentang bahasa yang dikaitkan dengan kondisi kemasyarakatan (dipelajari oleh ilmu-ilmu sosial khususnya sosiologi). Manusia dalam kondisi kemasyarakatan ialah berinteraksi dengan kelompok sosial lain dengan saling berkomunikasi menggunakan bahasa, karena dalam kehidupan masyarakat manusia tidak lagi sebagai makhluk individu, melainkan sebagai makhluk sosial sehingga Bahasa sangat penting digunakan oleh manusia dalam berbagai aktivitas kehidupan. Bahasa memiliki peran penting dalam kehidupan sosial. Sebagaimana telah dinyatakan oleh Fishman bahwa who speaks what language to whom and when (Fishman, 2012, p.15). Sosiolinguistik menyoroti keseluruhan masalah yang berhubungan dengan organisasi sosial perilaku bahasa, tidak hanya mfncakup pemakaian bahasa saja, melainkan juga sikap-sikap bahasa, perilaku terhadap bahasa saja dan pemakai bahasa (Sumarsono, 2013, p.2). 


\section{LingTera, 5 (1), 2018 - 2}

\section{Ruth Remilani Simatupang, Muhammad Rohmadi, Kundharu Saddhono}

Bahasa memiliki peran yang sangat penting di dalam kehidupan manusia. Sebab dengan adanya bahasa, hubungan antar masyarakat di suatu tempat akan lebih lancar. Ada masyarakat atau bangsa yang berhasil mengangkat salah satu dari bahasa daerahnya untuk keperluan yaitu bangsa Indonesia. Bahasa Indonesia semula merupakan bahasa Melayu-Riau. Namun karena bahasa daerah Melayu-Riau itu merupakan lingua franca bagi sebagian besar masyarakat bangsa Indonesia, maka diangkat dan ditetapkan sebagai bahasa nasional. Indonesia memiliki beratus-ratus bahasa daerah yang pada umumnya merupakan bahasa ibu; bahasa Indonesia (BI) sebagai bahasa kedua; dan bahasabahasa lain seperti bahasa Inggris, Arab, Jerman, sebagai bahasa asing. Dengan demikian, masyarakat Indonesia merupakan dwibahasawan (bilingual) bahkan mulitibahasawan (multilingual). Akibat ditetapkannya kedudukan satu atau beberapa bahasa sebagai bahasa nasional, maka timbullah masalah bahasa-bahasa daerah seperti bahasa Batak Toba, Jawa, Bali, Bugis, dan sebagainya.

Bahasa-bahasa daerah dan bahasa asing dalam hubungannya dengan bahasa Indonesia sering menimbulkan masalah antara lain terjadinya interfensi, integrasi, maupun kesalahan dalam fungsi pemakaiannya dan masalah bahasa asing yang merupakan bahasa yang bukan bahasa asli yang dipergunakan dan hidup dinegara itu disamping bahasa nasional. Pada dasarnya, interferensi dan integrasi mempunyai pengertian yang sama, yaitu peristiwa pemakaian unsur bahasa yang satu ke dalam unsur bahasa yang lain terjadi dalam diri si penutur (Aslinda, 2014, p.65). Bahasa sering dianggap sebagai produk sosial atau produk budaya, bahkan merupakan bagian tak terpisahkan dari kebudayaan itu Karena bahasa adalah salah satu unsur kebudayaan, tidak selalu mudah untuk membedakan antara konvensi budaya (Wijana, 2012, p.143). Untuk mengatasi masalah yang timbul sebagai akibat adanya perubahan dari setiap komponen bahasa terse-but, maka diperlukan rekayasa bahasa dengan membuat perencanaan yang menyeluruh, terpe-rinci, bertahap, dan berkesinambungan dengan perkataan lain diperlukan rekayasa kode bahasa. Yang dimaksud dengan kode bahasa ialah sistem bahasa dalam suatu masyarakat. Oleh karena itu, pemilihan variasi kode yang tepat dalam berkomunikasi merupakan hal yang sangat penting.
Penutur dapat menyesuaikan perilaku kebahasaan dalam reaksi terhadap lawan bicara dengan mengubah ujaran bahasa lain, memakai kata-kata dari bahasa lain. Penelitian yang telah dilakukan oleh (Singh \& Afifah., 2012, pp.6475) dan (Masitoh, 2013, pp.28-33) Penelitian mereka berfokus pada pemakaian bahasa. Penutur menyelipkan bahasa lain ketika sedang menggunakan bahasa tertentu dalam pembicaraannya. Unsur-unsur yang diambil dari bahasa lain itu sering kali berwujud kata-kata, juga berwujud frase, berwujud perulangan kata, berwujud idiom atau ungkapan maupun berwujud klausa.

Sosiolinguistik mengkaji pilihan bahasa dalam penggunaan bahasa. pilihan bahasa terdapat pada masyarakat aneka bahasa yaitu masyarakat yang menguasai dua atau beberapa bahasa yang harus dipilih pada saat dia berbicara. Ada jenis pilihan bahasa yaitu alih kode dan campur kode. Pertama, alih kode. Alih kode merupakan peralihan suatu kode ke kode lain dengan tujuan agar penutur dengan mitra tuturnya membangun keakraban. Jika misalnya si A mempunyai B1 bahasa Batak (bahasa daerah Sumatera Utara) dan B2 bahasa Indonesia serta menguasai bahasa Inggris, dia dapat beralih kode dengan ketiga bahasa tersebut. Bahasa yang dipilih bergantung pada banyak faktor, antara lawan tutur, topik dan suasana. Alih kode juga dapat ditemukan di lingkungan pendidikan pada saat proses pembelajaran di sekolah khususnya pada penelitian ini. Pada saat proses pembelajaran berlangsung siswa dan guru sering menggunakan alih kode.

Alih kode merupakan gejala peralihan pemakaian bahasa karena berubah situasi (Appel dkk, 1976, p.103). Berbeda dengan Hymes yang mengemukakan bahwa alih kode bukan hanya terjadi antarbahasa, melainkan juga terjadi ragam-ragam bahasa dan gaya bahasa yang terdapat dalam satu bahasa (Hymes, 1964, p.103). Hymes juga mengemukakan beberapa faktorfaktor dalam suatu interaksi pembicaraan yang dapat mempengaruhi penetapan makna, yaitu: siapa pembicara atau bagaimana pribadi pembicara, dimana atau kapan pembicaraan itu berlangsung, apa modus yang digunakan, apa topik atau subtopik yang dibicarakan, apa fungsi dan tujuan pembicaraan, apa ragam bahasa dan tingkat tutur yang digunakan. Namun kedua pandangan tersebut sangat dipengaruhi oleh kesadaran dan penyebab suatu situasi. Masyarakat multilingual sangat sulit menggunakan satu bahasa, hal ini alih kode mendukung fungsi 


\section{LingTera, 5 (1), 2018 - 3}

\section{Ruth Remilani Simatupang, Muhammad Rohmadi, Kundharu Saddhono}

sesuai dengan konteksnya. (Suwito, 1983, p.69) membagi alih kode menjadi dua yaitu:alih kode ekstern dan alih kode intern.

Alih kode ekstern, apabila terjadi alih bahasa antara bahasa asli dengan bahasa asing, seperti bahasa Indonesia ke bahasa Inggris atau sebaliknya.

Alih kode intern, apabila alih kode terjadi antar bahasa-bahasa daerah ke dalam satu bahasa nasional, atau antara dialek-dialek dalam satu bahasa daerah atau beberapa ragam dan gaya yang terdapat dalam satu dialek.

Peneliti juga menemukan beberapa alih kode ekstern pada saat proses pembelajaran yaitu guru maupun murid yang semula menggunakan bahasa Indonesia lalu beralih ke bahasa Inggris. Hal ini didukung oleh penelitian (Garing, 2014, pp.321-330)“ Alih Kode dan Campur Kode pada Tuturan Pertelevisian Indonesia" menyatakan bahwa alih kode yang dituturkan oleh pembawa cara televisi, para juri dan para peserta lomba menyanyi pada saluran televisi Indonesia adalah alih kode dari bahasa asing ke bahasa Indonesia atau yang disebut dengan alih kode ekstern. Hal tersebut juga didukung oleh penelitian (Rahmina, 2016, pp. 191-202) dengan judul penelitian " Penggunaan Alih Kode (Code Switching) dalam Pembelajaran Bahasa Inggris di MA mu'allimaat MuhammadiyahYogyakarta" menyatakan bahwa penggunaaan alih kode dalam pembelajaran bahasa Inggris di MA Mueallimaat Muhammadiyah Yogyakarta terjadi sejumlah 166 data. Selanjutnya, seluruh data terbagi dalam 2 jenis alih kode, yaitu; (1) intra-sentential code switching terjadi sejumlah 61 data $(37 \%)$, dan (2) inter-sentential code switching terjadi sejumlah 105 data (63\%).

Jenis pilihan bahasa yang kedua ialah campur kode. Campur kode ialah penutur dimana pada saat mengungkapkan sesuatu menyelipkan bahasa daerah maupun bahasa asing ke dalam pembicaraan bahasa Indone-sia. Seorang penutur misalnya, dalam berbahasa Indonesia banyak menyelipkan bahasa daerahnya, maupun bahasa asing yang diketahui penutur tersebut, maka penutur itu itu dapat dikatakan telah melakukan campur kode. Dengan kata lain misalnya Ketika sedang memakai bahasa tertentu, si A dalam berbahasa bahasa Indonesia dia memasukkan unsur-unsur dari Batak dan ketika si A juga berbicara bahasa Indonesia dia memasukkan bahasa asing.

Perbedaan alih kode dan campur kode, bila didalam suatu peristiwa tutur terjadi peralihan dari satu klausa suatu bahasa ke klausa bahasa lain, maka peristiwa tersebut alih kode. Tetapi apabila di dalam peristiwa tutur, klausa-klausa maupun frase-frase yang digunakan terdiri dari klausa dan frase campuran, sehingga masingmasing klausa atau frase tidak mendukung fungsi sendiri-sendiri, maka peristiwa tersebut ialah campur kode bukan alih kode (Thelander, 1976, p.103) Campur kode adalah suatu keadaan berbahasa bilamana orang yang mencampur dua atau lebih bahasa dengan saling memasukkan unsur-unsur bahahsa yang satu ke dalam bahasa yang lain, unsur-unsur yang menyisip tersebut tidak lagi mempunyai fungsi sendiri (Suwito, 1983, p.68). Campur kode ada yang berwujud kata, kata ulang, kelompok kata, ungkapan maupun berwujud klausa. ciri yang menonjol dalam campur kode ialah kesantaian atau situasi informal. Sedangkan dalam formal jarang terjadi campur kode, kalau terdapat campur kode dalam keadaan itu karena tidak ada kata atau ungkapan yang tepat untuk menggantikan bahasa yang sedang dipakai sehingga perlu memakai kata atau ungkapan dari bahasa daerah atau bahasa asing (Nababan, 1991, p.32).

Campur kode dibagi menjadi dua yaitu campur kode ke dalam dan campur kode keluar. Campur kode kedalam ialah campur kode yang bersumber dari bahasa asli dengan segala variasinya. Sedangkan campur kode keluar adalah campur kode yang berasal dari bahasa asing. Misalnya seorang penutur menyelipkan bahasa daerah dalam pembicaraan bahasa Indonesia sehingga penutur tersebut menggunakan campur kode ke dalam sedangkan jika pada saat penutur mengungkapkan unsur bahasa asing saat pembicaraan bahasa Indonesia disebut campur kode keluar.

Rumusan masalah dalam penelitian ini adalah, bagaimana bentuk-bentuk alih kode dan campur kode pada tuturan penutur di Sekolah Menengah Kejuruan (SMK) Swasta Marisi kota Medan pada mata pelajaran bahasa Indonesia?

Peneliti pada saat melakukan penelitian di SMK Swasta Marisi Medan banyak menemukan alih kode yang digunakan guru dan siswa. Pada lingkungan SMK Swasta Marisi Medan terdapat tiga pilihan bahasa yang digunakan yaitu bahasa Indonesia, bahasa Batak dan bahasa Inggris. Medan merupakan suatu provinsi yang terletak di Sumatera Utara memiliki beberapa bahasa yaitu Melayu, Batak, Jawa dan lain-lain. Pada saat guru bertanya dengan bahasa Indonesia, di SMK Swasta Marisi Medan siswa menjawab pertanyaan guru dengan menggunakan alih kode 


\section{LingTera, 5 (1), 2018 - 4}

Ruth Remilani Simatupang, Muhammad Rohmadi, Kundharu Saddhono

bahasa Batak. Karena siswa dan guru memiliki latar belakang suku Batak. Hasil wawancara yang dilakukan oleh peneliti dengan dua guru bahasa Indonesia yaitu Ibu Rahmi Serihanida Pulungan dan Ibu Twentyna Fivebrin Sitinjak serta siswa-siswa tersebut mengatakan bahwa di luar sekolah maupun di rumah mereka sering menggunakan bahasa Batak. Sehingga hal tersebut menjadi kebiasaan yang mereka lakukan di sekolah. Hal ini didukung hasil penelitian yang dilakukan oleh (Susmita, 2015, pp. 87-98) dengan judul penelitian "Alih Kode dan Campur Kode dalam Pembelajaran Bahasa Indonesia di SMP Negeri 12 Kerinci" menyatakan bahwa dalam proses pembelajaran khususnya pembelajaran bahasa Indonesia cenderung menggunakan alih kode dan campur kode (bahasa Melayu, Kerinci, Jambi dan Minangkabau). Alih kode yang sering digunakan guru dan siswa memiliki alasan dan fungsi yang jelas.

Dari uraian tersebut peneliti menggunakan pendapat yang telah dikemukakan (Susmita, 2015) tentang alih kode dan campur kode dalam pembelajaran bahasa Indonesia di kelas. Hal tersebut terjadi karena penelitian yang telah dilakukan tersebut adalah pendapat yang paling mendekati dalam pembahasan penelitian ini yaitu alih kode dan campur kode dalam pembelajaran bahasa Indonesia di kelas.

\section{METODE}

Penelitian ini merupakan metode deskriptif kualitatif. Penelitian ini dilakukan di SMK kota Medan yakni SMK Swasta Marisi Medan. Subjek dalam penelitian ini adalah guru dan siswa. Objek dalam penelitian ini adalah tuturan penggunaan alih kode dan campur kode yang digunakan pada saat pembelajaran bahasa Indonesia. Pengumpulan data digunakan dengan teknik pengamatan, teknik wawancara, dan teknik rekam. Instrumen utama dalam pengumpulan data adalah peneliti. Selain itu, peneliti juga menggunakan instrumen berupa pedoman pengamatan dan pedoman wawancara. Data dalam penelitiaan ini berupa alih kode dan campur kode dalam wujud kata ulang, ungkapan, frase dan penyisipan kata kemudian dianalisis secara kualitatif berdasarkan jenisnya yakni jenis dalam dan luar.

\section{HASIL DAN PEMBAHASAN}

Berdasarkan hasil penelitian yang ditemukan dalam proses pembelajaran bahasa Indonesia di SMK Kota Medan yaitu SMK Swasta Marisi Medan dan terdapat bentuk alih kode dan campur kode pada tuturan di lingkungan pendidikan tersebut baik guru maupun siswa. Sehingga bentuknya dapat kita lihat sebagai berikut.

\section{Alih Kode}

Alih kode merupakan peralihan suatu kode ke kode lain dengan tujuan agar penutur dengan mitra tuturnya membangun keakraban. Alih dapat ditemukan sebagai berikut:

\section{Data 1}

Guru: Ada yang tidak sarapan tadi pagi?

Siswa: Ada bu, si Maria belum

Guru: Boasa dang sarapan ho Maria?

Maria: Terlambat dungo au bu Gabe dang sempat.

Terjemahannya

Guru: Ada yang tidak sarapan tadi pagi?

Siswa: Ada bu, si Maria belum

Guru: Mengapa kamu tidak makan Maria?

Maria: Saya bangun kesiangan bu, saya tidak sempat makan.

Data 1 merupakan alih kode berupa kalimat Tanya yang digunakan guru dan siswa pada saat proses pembelajaran yaitu guru melihat siswanya (Maria) dalam keadaan lemas sehingga guru menanyakan ke siswanya apakah ada yang belum sarapan. Data tersebut bersifat situasional yang merupakan alih kode yang sifatnya karena situasi dimana guru bertanya pada salah seorang siswa. Hal ini terjadi karena guru dan siswa merupakan multilingual, sehingga guru dan siswa dapat beralih kode. Data tersebut ialah alih kode dari bahasa Indonesia ke bahasa Batak yang semula gurunya bertanya menggunakan bahasa Indonesia namun setelah mengetahui bahwa Maria berasal dari daerah pelosok yang masih sangat kental dengan bahasa daerah sehingga guru tersebut menanyakan kembali maria dengan pakai bahasa Batak.

\section{Data 2}

Guru: Semua membuka buku paketnya disana ada tentang teks hasil observasi! Lihat contoh sebagai tugas buatlah teks laporan hasil observasi sekolah kita ini.

Siswa 1: Semua di observasi bu? Sampai ukuran ruangan?

Guru: Iya semuanya

Siswa 2: Ai sohuboto sadia ukuran ni ruangan kelas on ibu. Sadia bu? Molo perpustakaan dohot bu

Guru: Lane tu kantor guru bereng adong disi tempelan ni biodata sekolah 


$$
\text { Ling Tera, } 5 \text { (1), } 2018 \text { - } 5
$$

Ruth Remilani Simatupang, Muhammad Rohmadi, Kundharu Saddhono

Siswa 1: Ikut aku ya bu

Guru: Olo dohot pe ho

Terjemahannya

Guru: Semua membuka buku paketnya disana ada tentang teks hasil observasi!

Lihat contoh sebagai tugas buatlah teks laporan hasil observasi sekolah kita ini.

Siswa 1: Semua di observasi bu? Sampai ukuran ruangan?

Guru: Iya semuanya

Siswa 2: saya kurang tahu ukuran kelas ini bu, berapakah ukuran kelas ini bu? Apakah perpustakaan ikut juga dilaporkan dalam teks ini bu?

Guru: kamu ke kamtor saja dulu lihat disana ada tempelan tentang biodata sekolah.

Siswa 1: ikut aku ya bu

Guru: Olo dohot pe ho.

Data 2 adalah salah satu alih kode yaitu guru yang semula memberikan penjelasan tentang teks hasil observasi kemudian guru menyuruh siswanya membuka buku materi pelajaran dan siswa disuruh mengerjakan soal yang ada di dalam buku tersebut. Di sana ada tentang membuat suatu teks hasil observasi berupa lingkungan sekolah. Pada awalnya guru menyuruh dengan menggunakan bahasa Indonesia dan salah seorang siswa 1 menyanggah dengan bahasa Indonesia juga namun tidak lama kemudian ada siswa 2 yang menyanggah dengan bahasa Batak yaitu menanyakan ukuran ruangannya kepada guru dan guru memberikan responnya dengan bahasa Batak juga namun siswa 1 yang notabene dia tinggal di kota Medan dia kembali bertanya dengan bahasa Indonesia namun karena sering mendengar bahasa Batak sehingga guru membalasnya dengan bahasa Batak kembali karena si guru tahu bahwa kata yang dituturkan sebelumnya pasti diketahui siswa 1 karena siswa 1 merupakan orang bersuku Batak. Data diatas merupakan alih kode yang bersifat situasional dimana guru dan siswa dikelas pada saat pembelajaran membahas tentang materi pembelajaran teks hasil observasi dimana guru dan siswa menggunakan alih kode karena siswa dan guru merupakan multilingual yang menggunkaan bahasa Indonesia dan bahasa Batak. Data tersebut merupakan alih kode dari bahasa Indonesia ke bahasa Batak.

\section{Data 3}

Guru: Yegar baca bukumu halaman 78

Yegar: Halaman berapa ya bu?
Guru: 78 Ai lam nengel si yegar on makana tujolo bereng.

Yegar: Siap bu.

Terjemahannya

Guru: Yegar baca bukumu halaman 78

Yegar: halaman berapa ya bu?

Guru: 78 Makin lama makin tuli kamu yegar Yegar: siap bu.

Data 3 merupakan alih kode yang bersifat situasional. Pada saat guru menyuruh salah satu siswanya yang bernama Yegar membaca buku pelajaran halaman 78 dimana pada awalnya guru menyuruh dengan menggunakan bahasa Indonesia, karena berdasarkan siatuasi melihat siswa yang bernama tegas berasal dari suku Batak toba lalu gurunya beralih dengan menggunakan bahasa Batak. Peristiwa tersebut merupakan alih kode karena guru merupakan multilingual yang dpat menggunakan lebih dari satu bahasa yaitu bahasa Indonesia dan bahasa Batak. Data diatas merupakan alih kode dari bahasa Indonesia ke bahasa Batak.

\section{Data 4}

Guru: Hari ini yang tidak masuk siapa?

Siswa: Robert bu

Guru: (melihat salah satu siswanya menguap, guru langsung menegur) patalak babami Agus balga ai na so modom doho nabodari?

Terjemahannya

Guru: Hari ini yang tidak masuk siapa?

Siswa: Robert bu

Guru: (melihat salah satu siswanya menguap, guru langsung menegur) kurang lebar mulutmu itu agus, kau tidak tidur semalam?

Data 4 merupakan salah satu alih kode berupa kalimat Tanya yaitu guru yang semula menggunakan bahasa Indonesia pada awal pembelajaran namun pada saat guru melihat salah satu siswa yang bernama agus menguap guru menegur dan bertanya. Hal ini menunjukkan bahwa guru termasuk multilingual karena guru dapat menggunakan dua bahasa sekaligus dalam satu peristiwa kegiatan pembuka pelajaran. Dalam hal ini guru menggunakan alih kode dari bahasa Indonesia ke bahasa Batak.

\section{Campur Kode}

Campur kode memiliki berbagai bentuk atau wujud. Campur kode ada yang berbentuk kata, kata ulang, kelompok kata, ungkapan dan klausa. 


$$
\text { LingTera, } 5 \text { (1), } 2018 \text { - } 6
$$

Ruth Remilani Simatupang, Muhammad Rohmadi, Kundharu Saddhono

Campur Kode yang Berbentuk Kata

Campur kode yang terjadi pada saat pembelajaran bahasa Indonesia memiliki berbagai bentuk atau wujud. Salah satunya merupakan Campur kode yang berbentu kata.

\section{Data 5}

Guru: Kenapa tidak ada cover Kliping kelompokmu?

Siswa: Maaf bu kami lupa membuatnya

Guru: Besok kepala kalian Tinggalkan juga ya. Ibu tidak mau tahu Pokoknya besok harus complete.

Data 5 merupakan peristiwa campur kode ke luar (outer code switching) karena di sana ada pernyataan guru ke siswa yang menyelipkan unsur bahasa asing berupa bahasa Inggris yaitu kata cover dan complete. Cover dalam bahasa Indonesia ialah penutup atau sampul sedangkan complete ialah lengkap. Hal ini merupakan peristiwa campur kode ke luar karena dalam hal ini guru merupakan seorang penutur dwibahasawan yang memahami dua bahasa yaitu bahasa Inggris dan bahasa Indonesia. Dalam peristiwa ini tuturan kalimat yang diucapkan guru tersebut ialah untuk menyurus siswanya dalam membuat sampul sebagai pendukung dari kliping tersebut karena guru menginginkan kliping yang lengkap. Untuk mengungkapkan kelengkapan sebuah kliping guru tersebut memilih unsur bahasa Inggris complete (lengkap).

\section{Data 6}

Siswa 1: Bu apakah tugasnya dikerjakan bagian A dan B?

Guru: Iya semua dikerjakan di rumah sebagai note tidak boleh sama dengan temannya nanti nilainya saya kurangi.

Data 6 merupakan peristiwa campur kode ke luar (outer code switching) karena di sana ada pernyataan seorang guru kepada siswa yang sedang menanyakan tugas. Dengan penekanan pemilihan bahasa guru tersebut menggunakan bahasa asing yakni bahasa Inggris terhadap semua siswanya. Guru tersebut menggunakan bahasa Inggris yaitu note (catatan) Oto dalam bahasa Indonesia ialah bodoh. Maksud dan tujuan guru tersebut ialah supaya siswanya mengerjakan tugasnya secara mandiri bukan kelompok supaya tugas yang diberikan guru tersebut tidak sama jawabannya antara siswa yang satu dengan yang lain. Peristiwa tersebut terjadi karena guru dalam konteks ini merupakan dwi- bahasawan yang dapat memahami dua bahasa yaitu bahasa Inggris dan bahasa Indonesia.

\section{Data 7}

Guru: Oto sekali kalian mengerjakan itu saja tidak bisa

Siswa: Sulit bu.

Data 7 merupakan peristiwa campur kode ke dalam (inner code switching) karena di sana ada pernyataan guru ke siswa yang menyelipkan unsur bahasa daerah berupa bahasa Batak yaitu kata oto. Oto dalam bahasa Indonesia ialah bodoh. Hal ini merupakan peristiwa campur kode ke dalam karena dalam hal ini guru merupakan seorang penutur dwibahasawan yang memahami dua bahasa yaitu bahasa Batak dan bahasa Indonesia. Dalam peristiwa ini guru tersebut selain menguasai bahasa ibu sebagai bahasa asli atau pertama guru tersebut juga menguasai bahasa Indonesia sebagai bahasa kedua. maksud dari penutur yaitu guru ialah menegaskan kepada siswanya bahwa tugas yang ingin dikerjakan siswanya itu merupakan tugas yang sangat mudah. Sehingga guru memberi tanggapan berupa sindiran supaya siswanya tidak langsung menyerah dalam mengerjakan tugas tersebut.

\section{Campur Kode yang Berbentuk Kelompok Kata}

Peristiwa campur kode pada saat pembelajaran bahasa Indonesia tidak hanya berwujud kata, akan tetapi ada juga yang berbentuk kelompok kata yaitu sebagai berikut.

\section{Data 8}

Guru: tutup dengan bagus Ai use annong Siswa: iya bu

Data 8 merupakan peristiwa campur kode ke dalam (inner code switching) karena di sana ada pernyataan guru ke siswa yang menyelipkan unsur bahasa daerah berupa bahasa Batak yaitu kelompok kata Ai use annong (jatuh nanti). Dalam peristiwa ini tuturan kalimat yang diucapkan guru tersebut ialah untuk menyuruh siswanya untuk menutup kembali botol cairan tiner dengan baik supaya tidak jatuh ke lantai. Tuturan itu terjadi karena guru merupakan dwibahasawan yang dapat menggunakan dua bahasa sekaligus dalam satu tanggapan berupa kelompok kata. Selain kelompok kata yang berupa campur kode ke dalam, ada juga data kelompok kata yang bercampur kode keluar yaitu sebagai berikut.

\section{Data 9}

Guru: Hapus papan tulis itu ias baen

Siswa: Siap bu 


\title{
LingTera, 5 (1), 2018 - 7
}

\author{
Ruth Remilani Simatupang, Muhammad Rohmadi, Kundharu Saddhono
}

Data 9 merupakan peristiwa campur kode ke dalam (inner code switching) karena guru menyelipkan unsur bahasa daerah berupa bahasa Batak yaitu kelompok kata ias baen (buat dengan bersih). Dalam peristiwa ini tuturan kalimat yang diucapkan guru tersebut ialah untuk menyuruh siswanya untuk membersihkan papan tulis bekas tulisan guru yang mengajar di kelas itu sebelumnya. Guru tersebut merupakan dwibahasawan sebab dia menggunakan bahasa Indonesia dengan menyelipkan unsur bahasa daerah yaitu Batak dalam menyuruh siswanya yang notabene juga merupakan orang Batak. Sehingga tuturan antara guru dan siswa menunjukkan maksud dan tujuan tertentu yang saling memahami.

\section{Campur Kode yang Berbentuk Kata Ulang}

Peristiwa campur kode pada saat pembelajaran bahasa Indonesia ada juga yang berbentuk kata ulang yaitu sebagai berikut.

\section{Data 10}

Siswa 1: Mar, jangan ngatngati pulpenku udah minjam pun kok kamu buat gitu

Siswa 1: Berlebihan sekali kamu pulpen ini saja pun

Guru: Hush segera dikerjakan tugasnya

Data 10 merupakan peristiwa campur kode ke dalam (inner code switching) karena di sana ada ditemukan pernyataan antara siswa dan guru. Pada awalnya siswa menggunakan bahasa Indonesia namun dia menyelipkan unsur bahasa daerah berupa bahasa Batak kepada salah satu temannya yang merupakan suku Batak. Di sana siswa 1 (pertama) melihat teman sebangkunya menggigit pupen yang merupakan pulpen siswa 1 yang dipinjam oleh siswa 2 sehingga dia memarahi temannya untuk tidak menggigit pulpen siswa pertama. Karena siswa pertama merupakan dwibahasawan sehingga siswa 1 menyelipkan unsur bahasa daerah berupa bahasa Batak dengan kata ulang ngatngat dalam arti gigit (menggigit). Dalam konteks ini siswa pertama melarang siswa kedua melihat siswa kedua mengigit ujung pulpennya secara terus menerus sehingga dia menggunakan campur kode dengan bentuk perulangan. Melihat tingkah mereka yang rebut antara siswa pertama dan kedua sehingga guru memberi sanggahan supaya kedua siswa tersebut tidak ribut.

\section{Data 11}

Guru: Semua berdiri tidak ada yang duduk hari ini supaya tidak mengantuk apalagi ini jam terakhir supaya merilekskan badan. Kenapa si Yason ini susah sekali jongjong

Data 11 merupakan peristiwa campur kode ke dalam karena di sana ada ditemukan pernyataan guru ke salah seorang siswa. Maksud dari tujuan guru tersebut ialah membangkitkan semangat siswanya dengan menyuruh semua siswa berdiri. Namun ada salah seorang siswa tidak berdiri sehingga guru tersebut menyuruhnya untuk bangkit berdiri dengan kata jongjong artinya berdiri itu merupakan salah satu campur kode ke dalam (inner code switching). Pernyataan tersebut terjadi karena guru merupakan dwibahawan yang mampu menggunakan dua bahasa yaitu bahasa Indonesia dan bahasa Batak. Sehingga pada saat menyuruh siswa untuk bangkit berdiri melihat salah seorang siswa yang dia tahu bahwa dia juga merupakan suku Batak, guru menyelipkan unsur bahasa daerah berupa bahasa Batak yang merupakan bahasa asli (B1) atau bahasa pertama ke dalam bahasa Indonesia atau bahasa kedua (B2). Namun dalam kata ulang tersebut maknanya hanya satu yaitu berdiri.

\section{Campur Kode yang Berbentuk Ungkapan}

Peristiwa campur kode pada saat pembelajaran bahasa Indonesia ada juga yang berbentuk ungkapan. Ungkapan-ungkapan yang ditemukan peneliti di SMK Swasta Marisi Medan ialah berikut ini.

\section{Data 12}

Guru: Kenapa kamu tidak bisa diam dari tadi berisik terus terganggu konsentrasi belajar temanmu. Sudah salah tetap juga berisik menjawab-jawab guru. Jolo nidilat bibir asa manghatai.

Data 12 merupakan campur kode yang berbentuk ungkapan berupa campur kode ke dalam (inner code switching) karena dalam pernyataan tersebut ialah terdapat guru sedang menasehati salah seorang siswanya yang tidak memperdulikan guru pada saat menjelakan di depan kelas. Akhirnya guru menasehati dengan bahasa Indonesia dan menyelipkan unsur bahasa daerah berupa bahasa Batak. Guru menggunakan ungkapan Jolo nidilat bibir asa manghatai (sebelum menuturkan sesuatu atau membicarakan sesuatu terlebih dahulu dipikirkan apa yang hendak ingin dibicarakan) jadi tidak langsung mengeluarkan bisa lidah tersebut. Maksud dan tujuan guru menyatakan hal tersebut ialah supaya murid tersebut tidak asal bunyi sebaiknya 


$$
\text { LingTera, } 5 \text { (1), } 2018 \text { - } 8
$$

Ruth Remilani Simatupang, Muhammad Rohmadi, Kundharu Saddhono

berpikir dan guru tersebut mengajarkan kedisplinan kepada murid tersebut. Guru tersebut merupakan dwibahasawan yang mengetahui dua bahasa yakni bahasa Batak dan bahasa Indonesia.

\section{Data 13}

Guru: Sebaiknya pada jam istirahat kalian pergi ke perpustakaan menambah ilmu kalian supaya waktu itu tidak berlalu begitu saja jangan menyia-yiakan waktu sebab time is money

Data 13 merupakan peristiwa peristiwa campur kode ke luar (outer code switching) karena dalam tuturan tersebut guru menggunakan bahasa Indonesia namun pada inti tuturannya guru tersebut menyelipapkan unsur bahasa asing yaitu bahasa Inggris dengan kata time is money (waktu adalah uang). Maksud dari tuturan guru tersebut ialah menasehati siswanya supaya tidak menghabiskan waktu dengan siasia sebaiknya menggunakan waktu dengan baik seperti pergi ke perpustakaan untuk membaca buku baik itu novel, ensiklopedia maupun lainlain seperti ungkapan orang asing time is money. Peristiwa tersebut terjadi karena guru merupakan dwibahasawan sehingga guru dalam menasehati dia menyelipkan unsur bahasa asing dengan bahasa Inggris.

\section{Data 14}

Guru: Siapa kemaren yang cabut pada jam terakhir pembelajaran jangan suka berbohong ingat pendek do pat ni gabus

Data 14 merupakan campur kode yang berbentuk ungkapan berupa campur kode ke dalam (inner code switching). Karena dalam peristiwa tersebut guru bertanya kepada siswa yang ada di kelas yang pulang sebelum waktunya pulang sekolah namun tidak ada yang mengakuinya. Dalam hal tersebut guru menggunakan bahasa Indonesia dan menyelipkan bahasa daerah yaitu bahasa Batak dengan ungkapan pendek do pat ni gabus (langkah seorang pembohong tidak akan berguna). Maksud ungkapan guru tersebut ialah supaya siswa jujur sehingga guru tersebut menyelipkan ungkapan bahasa Batak di akhir tuturannya.

\section{Campur Kode yang Berbentuk Klausa}

Peristiwa campur kode pada saat pembelajaran bahasa Indonesia tidak hanya berwujud kata maupun kelompok kata, tetapi ada juga yang berbentuk klausa. Campur kode yang berbentuk klausa yaitu sebagai berikut.

\section{Data 14}

Siswa: Bu biasanya aku tidak semalas sekarang bu. Tapi tidak tahu kenapa na malasan au dobah

Data 14 merupakan peristiwa campur kode ke dalam (inner code switching) yang berbentuk klausa karena di sana ada pernyataan siswa ke guru yang semula siswa tersebut menggunakan bahasa Indonesia namun siswa tersebut menyelipkan unsur bahasa daerah berupa bahasa Batak yaitu dengan kata na malasan au dobah (akhir-akhir ini aku malas sekali). Maksud dari pernaytaan siswa tersebut ialah bahwa dulu dia sangat rajin untuk mengerjakan sesuatu namun belakangan ini dia mulai malas. Siswa dalam konteks ini merupakan dwibahasawan yang menggunakan bahasa Indonesia dan bahasa Batak dalam suatu situasi yang sama. Dalam hal tersebut siswa menyelipkan unsur bahasa Batak ke tuturannya yang semula bahasa Indonesia.

\section{Data 15}

Guru: Kalau sudah selesai tugasnya nanti dikumpul pada saat jam terakhir tidak ada alasan sulit dikerjakan yang penting bukunya dibaca pasti jawaban dapat ditemukan you understand what I mean?

\section{Siswa: Yes}

Data 15 merupakan peristiwa campur kode keluar (outer code switching) yang berbentuk klausa karena disana ada pernyataan antara siswa ke guru dimana guru menggunakan bahasa Indonesia dan menyelipkan unsur bahasa asing berupa bahasa Inggris yaitu dengan klausa you understand what I mean? Maksud dari pertanyaan tersebut ialah apakah para siswa mengerti apa yang guru tuturkan sebelumnya bahwa tugas harus dikumpulkan pada jam akhir, lalu semua siswa harus membaca bukunya dengan teliti. Maksud dan tujuan guru menggunakan kata demikian supaya siswa tidak mencari alasan dengan tidak mengumpulkan tugasnya pada jam terakhir. Lalu siswa juga menjawab pertanyaan dengan menyetujui apa maksud perkataan guru tersebut. Pada peristiwa ini guru menggunakan dua bahasa pada semula menggunakan bahasa Indonesia lalu menyelipkan bahasa Indonesia tersebut denga bahasa asing yaitu bahasa inggris lalu siswa juga membalas pertanyaan tersebut sesuai dengan konteks bahasa yang digunakan oleh guru tersebut dengan demikian guru dan siswa dalam konteks ini merupakan dwibahasawan yang menggunakan dua bahasa dalam situasi yang sama. 


$$
\text { LingTera, } 5 \text { (1), } 2018 \text { - } 9
$$

Ruth Remilani Simatupang, Muhammad Rohmadi, Kundharu Saddhono

\section{SIMPULAN}

Berdasarkan analisis data dalam penelitian ini dapat disimpulkan bahwa dalam proses pembelajaran khususnya pembelajaran bahasa Indonesia di SMK kota Medan terjadi dua pilihan bahasa yaitu alih kode dan campur kode. Wujud Alih kode yang digunakan ialah bahasa Indonesia ke bahasa Batak Toba dan sebaliknya dalam penelitian ini wujud alih kode terdapat 5 data percakapan antara guru dan siswa. Sedangkan campur kode yang digunakan dalam penelitian ini adalah campur kode ke dalam dan campur kode keluar yaitu dengan menggunakan bahasa Indonesia, bahasa Inggris dan bahasa Batak. Bentuk campur kode yang terjadi di SMK kota Medan yaitu SMK Swasta Marisi Medan ialah sebanyak 12 data percakapan antara guru dan siswa yang didalamnya terdapat bentuk kata, kelompok kata, kata ulang, ungkapan dan klausa.

\section{DAFTAR PUSTAKA}

Appel dkk. (1976). Sosiolinguistics. Utrech Antwerpen: Het Spectrum.

Aslinda, L. S. (2014). Pengantar sosiolinguistik. Bandung: PT Refika Aditama.

Fishman, J. A. (2012). Reading in the sociology of language. Den Haag: Mouton.

Garing, J. (2014). Alih kode dan campur kode pada tuturan di pertelevisian Indonesia. Sawerigading, 20(2), 321-330.

Hymes, D. (1972). Toward ethnographies of communication: The analysis of communicative events dalam language and social context by Giglioli, P. Paolo (ed.).
Masitoh, S. (2013). Campur kode Bahasa Indonesia ke dalam bahasa Jawa pada siaran Radio Jampi Sayah di radio SKB POP FM Gombong. ADITYA-Pendidikan Bahasa dan Sastra Jawa, 3(1), 28-33.

Nababan, P.W.J. (1991). Sosiolinguistik: Suatu Pengantar. Jakarta: PT.Gramedia.

Rahmina, R., \& Tobing, R. (2016). Penggunaan alih kode (code switching) dalam pembelajaran bahasa Inggris di MA Mu'allimaat Muhammadiyah Yogyakarta. LingTera, 3(2), 191-202. doi:http://dx.doi.org/10.21831/lt.v3i2.631 4

Singh, S. K. S. (2012). Code-switching among military cadet officers during group interaction. Procedia-Social and Behavioral Sciences, 66, 64-75.

Sumarsono. (2013). Sosiolinguistik. Yogyakarta: Sabda.

Susmita, N. (2015). Alih kode dan campur kode dalam pembelajaran Bahasa Indonesia di SMP Negeri 12 Kerinci. Jurnal Penelitian Universitas Jambi: Seri Humaniora, 17(2).

Suwito. (1983). Pengantar awal sosiolinguistik: teori dan problem. Surakarta: Henary.

Thelander, M. (1976). Code-switching or codemixing? International Journal of the Sociology of Language, 1976(10), 103124.

Wijana, I. D. P., \& Rohmadi, M. (2012). Sosiolinguistik: Kajian teori dan analisis. Pustaka Pelajar. 